\title{
THE ASSOCIATIONS BETWEEN METABOLIC SYNDROM COMPONENTS AND CHRONIC RENAL DISEASE AT GATOT SUBROTO HOSPITAL, JAKARTA
}

\author{
Adelina Enggar Pertiwi'), Muttia Amalia'²), Pritha Maya Savitri3) \\ 1)Study Program in Medicine, Faculty of Medicine, UPN "Veteran" Jakarta \\ 2)Department of Clinical Pathology, Faculty of Medicine, UPN "Veteran" Jakarta \\ 3)Department of Matra Health and Disaster Management, \\ Faculty of Medicine, UPN “Veteran” Jakarta
}

\begin{abstract}
Background: The incidence of chronic renal disease in Indonesia is increasing. Metabolic syndrome is one of the risk factors of chronic renal disease. Insulin resistance (type 2 diabetes mellitus, high fasting-blood glucose, glucose intolerance), hypertension, hypertriglyceridemia, low serum HDL level, obesity, and microalbuminuria are components of metabolic syndrome according to WHO criteria. Metabolic syndrome causes chronic inflammation and eventually damages renal cells. This study aimed to examine the associations between metabolic syndrom components and chronic renal disease.
\end{abstract}

Subjects and Method: This was a cross sectional study carried out at Gatot Subroto Hospital, Jakarta. A sample of 113 patients with chronic renal disease was selected for this study. The dependent variable was patient of chronic renal disease. The independent variable was metabolic syndrome components based on WHO criteria. The data of chronic renal disease were obtained from the medical record. The data were described in percent and analyzed by a multiple logistic regression.

Results: Of all 113 patients with chronic renal disease sample in this study, 66 (58.4\%) had metabolic syndrome. Chronic renal disease was associated with type 2 diabetes mellitus $(\mathrm{OR}=8.29 ; 95 \% \mathrm{CI}=0.77$ to $52.50 ; \mathrm{p}=0.049)$ and high fastingblood glucose level $(\mathrm{OR}=6.34 ; 95 \% \mathrm{CI}=1.01$ to $68.08 ; \mathrm{p}=0.087)$.

Conclusion: Type 2 diabetes mellitus and high fasting-blood glucose level are associated with an increased risk of chronic renal disease.

Keywords: chronic renal disease, metabolic syndrome, risk factor

\section{Correspondence:}

Muttia Amalia. Department of Clinical Pathology, Faculty of Medicine, Universitas Pembangunan Nasional 'Veteran', Jakarta, Jl. RS Fatmawati, Pondok Labu, South Jakarta. Email: muttia.aw@gmail.com. Mobile: 081296815742.

The 4th International Conference on Public Health Best Western Premier Hotel, Solo, Indonesia, August 29-30, 2018 | 296 https://doi.org/10.26911/theicph.2018.05.10 